\title{
Thermal Conductivity of Teak Wood from Thinned Stands
}

\author{
Veriawan Setyo Wibowo and Joko Sulistyo
}

\begin{abstract}
Wood has been utilized as a heat conductor or insulator. Hence, this research aims to discover the thermal conductivity of teak wood using thinned stands from the Perhutani plantation forest. The samples obtained had varying moisture content and fiber direction, and were of distinct tree ages, at 12, 15, 20, 25, and 60 years. This result show that the thermal conductivity in air-dry conditions and fiber saturation points were 0.116 to 0.128 and 0.338 to 0.151 in W/Mk, respectively. The analysis of variance showed that the thermal conductivity of teak wood was affected by the interaction of fiber directions and moisture content but not significantly by tree age. Also, there was a weak relationship found between thermal conductivity and specific gravity in air-dry conditions and longitudinal direction.
\end{abstract}

Keywords: tree age, thinning, Tectona grandis, anisotropy, density

\section{Introduction}

Wood is used as a raw material for various products, such as buildings or constructions, veneers, heat insulators, furniture, railway sleepers, sports equipment, etc. Also, the thermal properties of wood are necessary for several processes like wood drying, heat processing, building construction, and other fields of industry. Wood has a low thermal conductivity $(k)$ compared to other building materials due to its low density and hollow cellular structure.

Generally, teak species are classified as fancy and used in wooden industries in Indonesia. Recently, it has been supplied as young forms from community forests and thinned logs conventionally produced from $12,15,20,25$, and 60-year-old stands in the Perum Perhutani plantation forest. Although much research on the physical properties of young teak has been carried out (Marsoem et al. 2014; Hidayati et al. 2015), data on thermal conductivity are scanty.

Meanwhile, the thermal conductivity depends on several factors, namely species, density, moisture content, heat flow direction (anisotropy), alongside the inclination of grain (Suleiman et al. 1999), and correlates positively with the density of softwood and heartwood (Mauranen et al. 2015). Therefore, this research objective is to determine the thermal conductivity of teak wood from thinned stands at various ages and relate the values to its specific gravity.

\section{Materials and Methods}

\section{Material Preparation}

The research material was teak (Tectona grandis) from thinning cuttings in Randublatung Forest Management Unit, Central Java, obtained from tree samples from the bottom part of the tree, with age variations of $12,15,20,25$, and 60 years. For each age, three trees were selected. Meanwhile, the wood material used was in the form of randomly selected pieces free from defects and sound, which were cut and converted to produce specimen samples. These samples were used to test the heat conductivity of wood in a cylindrical shape with a $30 \mathrm{~mm}$ length and $25 \mathrm{~mm}$ diameter. The length dimensions were made in tangential and longitudinal directions (ASTM C177), while the samples for testing the water content and specific gravity were made with a size of $2 \times 2 \times 2 \mathrm{~cm}$ (British Standard 373-1957). Figure 1 describes the design scheme for making the specimens.

\section{Moisture Content Determination}

The moisture content (MC) was determined for ovendried, air-dry, and fiber saturation point (FSP) conditions at $0 \%, \pm 10 \%$, and $\pm 30 \%$, respectively. Before weighing periodically, the $10 \% \mathrm{MC}$ was obtained after air-drying the previously oven-dried samples, while the $30 \% \mathrm{MC}$ was achieved after immersing the oven-dried samples in water for a certain time until they reached a constant dimension (length and diameter). Then, the sample conditioned for its MC was wrapped in aluminum foil and put into a box containing silica. Subsequently, the MC was determined using the oven-drying method, while the wood sample was weighed and dried at $103 \pm 2{ }^{\circ} \mathrm{C}$ until the weight was constant. Also, the MC was determined, according to the formula MC $(\%)=[($ wet mass- dry mass $) /($ dry mass $)] \times 100$.

\section{Specific Gravity Determination}

The specific gravity (SG) of the wood specimens was calculated as oven-dry weight and volume, alongside the density of water. Meanwhile, density was calculated as the ratio of oven-dry weight to conditioned volume as determined by the water displacement method. 


\section{Thermal Conductivity Determination}

The measurement of thermal conductivity (TC) was carried out using a modified Armfield heat conduction apparatus (Laboratory of Pusat Antar Universitas, Universitas Gadjah Mada) based on the ASTM C177 method with modifications (Figure 2). Then, it was placed in a horizontal position on the apparatus with the direction of heat propagation parallel to the radial direction of the wood. The measurement was conducted for three replications. The initial heating was set at 4 watt. The initial temperatures of specimens were in the range of 24 to $30^{\circ} \mathrm{C}$. The heating duration was 130 minutes. The temperature changes at nine positions of the specimen (T1-T9) were recorded for every minute. The thermal conductivity values $(k)$ were calculated by the formula :

$$
k=\frac{Q d x}{A d t}
$$

$Q=$ the amount of heat transferred in a time (10 watt)

$A=$ specimen width

$\mathrm{dx}=$ specimen length $(30 \mathrm{~mm})$

$\mathrm{dt}=$ temperature gradient $(\mathrm{T} 4-\mathrm{T} 6)$

\section{Statistical Analysis}

The variation of the contents' TC was analyzed using the general linear model procedure by three-way analysis of variance (ANOVA), followed by the Tukey HSD test $(p=0.05)$. The factors were arranged in a factorial design for three replications, and the statistical calculations conducted using SPSS-Win 12.0 .

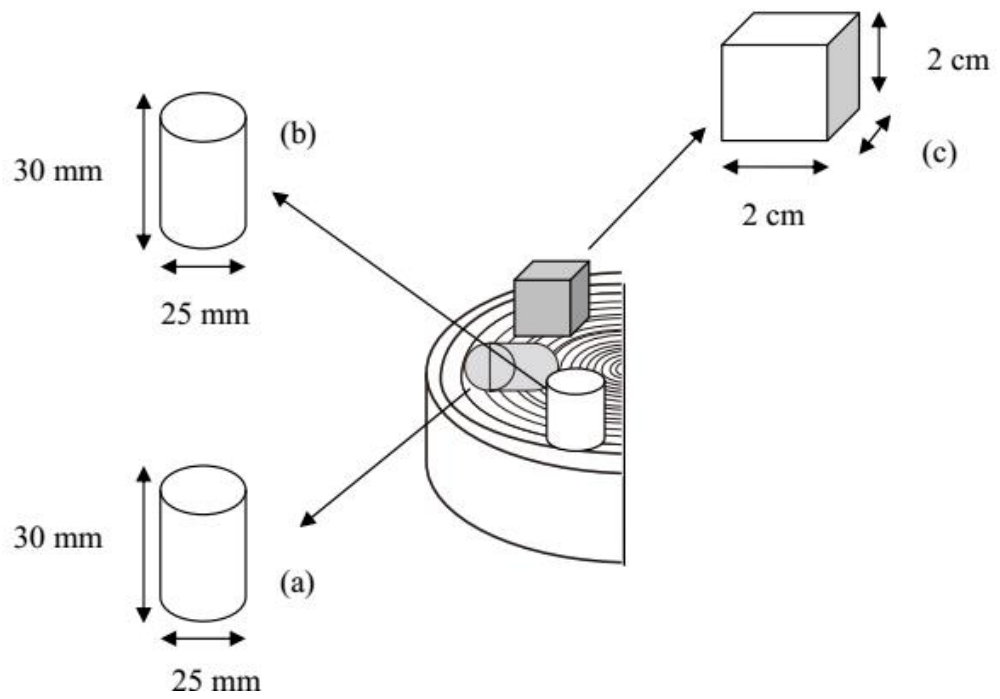

Figure 1. Schematic of the preparation process for samples in the longitudinal-tangential plane for thermal conductivity, moisture content, and specific gravity measurements.
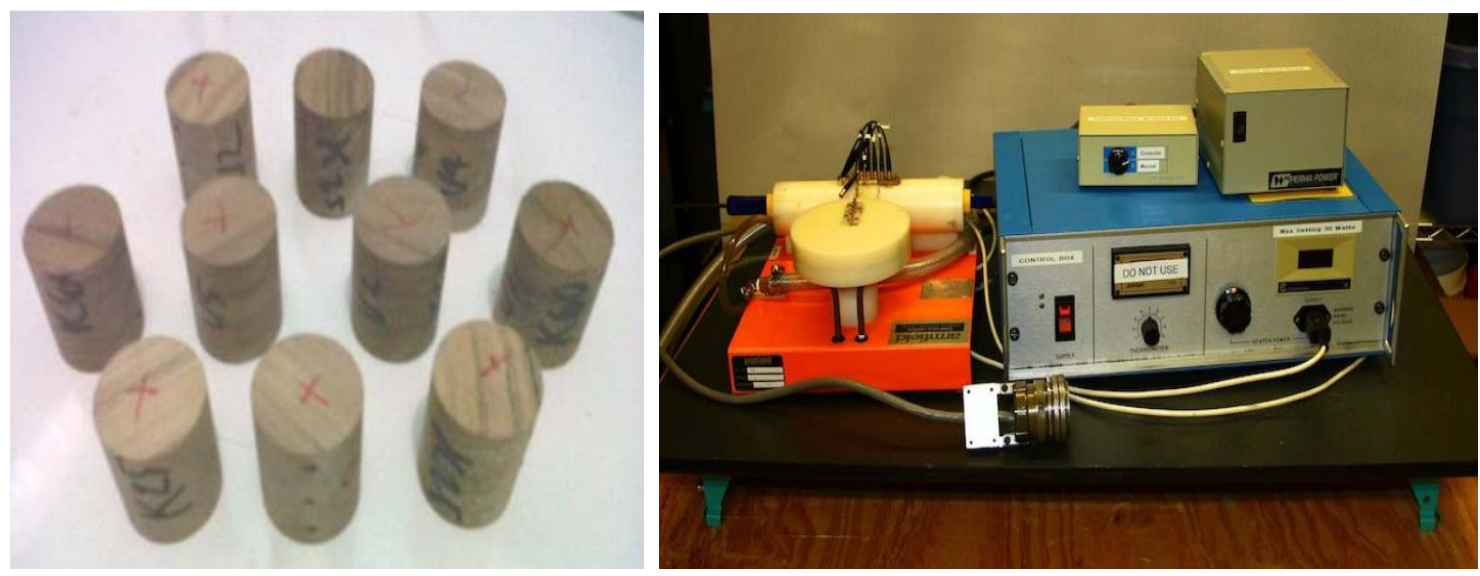

Figure 2. Specimens and instrument for measurement of thermal conductivity. 


\section{Results and Discussion}

This study relates the effect of MC to the value of TC from several tree ages with different fiber directions. The MC (air-dry) and FSP conditions ranging from 10 to $12 \%$ and $30 \pm 1 \%$, respectively, were set to observe the effect on the TC values. Tables 1 and 2 present the range of the MC and SG measurement values. Meanwhile, the SG value was in the range of young teak from the Gunungkidul community forest (Marsoem et al. 2014) but higher than young teak, aged 10 years, from Randublatung FMU (Hidayati et al. 2015).

Table 3 shows the TC values of teak wood from various tree ages with fiber direction and MC factors, 0.116 to 0.128 in W/mK at the air-dry condition and 0.338 to 0.151 $\mathrm{W} / \mathrm{mK}$ at FSP. Previous measurements (Prasojo et al. 2012) for teak wood obtained TC values of $0.110 \mathrm{~W} / \mathrm{mK}$ (oven-dry) to $0.142 \mathrm{~W} / \mathrm{mK}$ (FSP). The TC level in the FSP condition was higher than in the air-dry condition. Also, the
ANOVA results showed an interaction between $M C$ and fiber direction $(p>0.01)$, while the tree-age factor was not significantly affected. The post-hoc test result is presented in Figure 2. Meanwhile, the TC level was higher in the longitudinal than tangential direction at FSP but not in the air-dry conditions.

The TC value is very useful in processing wood, as a high value indicates the wood has good conductor properties, while a low value shows that the wood has poor conducting or good insulating properties. Also, the conductivity value of wood in the longitudinal direction had a heat conductivity value greater than $1-1.5$ than the tangential and radial directions due to the transverse and parallel position of the fiber direction to the tree axis (Siau 1995; Sonderegger et al. 2011). In addition, the difference in the TC value is also strongly influenced by variations in the MC of the wood, as water has conductor properties that adequately transmit heat.

Table 1. Moisture content (\%) of teak wood from various tree ages of thinned stands (mean of three trees)

\begin{tabular}{lccccc}
\hline Factors & \multicolumn{5}{c}{ Tree age (years) } \\
\cline { 2 - 6 } Moisture content/axis direction & 12 & 15 & 20 & 25 & 60 \\
\hline Fiber saturation point / Longitudinal & 30.90 & 31.05 & 31.05 & 31.12 & 30.97 \\
Fiber saturation point / Tangential & 31.02 & 30.71 & 30.38 & 30.62 & 30.09 \\
Air-dry / Longitudinal & 10.81 & 11.69 & 11.88 & 11.65 & 11.09 \\
Air-dry / Tangential & 11.92 & 12.52 & 12.22 & 12.56 & 11.20 \\
\hline
\end{tabular}

Table 2. Specific gravity of teak wood from various tree ages of thinned stands (mean of three trees)

\begin{tabular}{lccccc}
\hline Factors & \multicolumn{5}{c}{ Tree age (years) } \\
\cline { 2 - 6 } Moisture content/fiber direction & 12 & 15 & 20 & 25 & 60 \\
\hline Fiber saturation point / Longitudinal & 0.58 & 0.59 & 0.57 & 0.58 & 0.58 \\
Fiber saturation point / Tangential & 0.57 & 0.58 & 0.57 & 0.58 & 0.57 \\
Air-dry / Longitudinal & 0.59 & 0.61 & 0.58 & 0.58 & 0.60 \\
Air-dry / Tangential & 0.59 & 0.61 & 0.59 & 0.58 & 0.60 \\
Oven-dry / Longitudinal & 0.62 & 0.62 & 0.64 & 0.61 & 0.62 \\
Oven-dry / Tangential & 0.62 & 0.64 & 0.63 & 0.61 & 0.63 \\
\hline
\end{tabular}

Table 3. Thermal conductivity (W/mK) of teak wood from various tree ages of thinned stands (mean of three trees)

\begin{tabular}{lccccc}
\hline Factors & \multicolumn{5}{c}{ Tree age (years) } \\
\cline { 2 - 6 } Moisture content/fiber direction & 12 & 15 & 20 & 25 & 60 \\
\hline Fiber saturation point / Longitudinal & 0.148 & 0.148 & 0.148 & 0.150 & 0.151 \\
Fiber saturation point / Tangential & 0.139 & 0.142 & 0.144 & 0.138 & 0.143 \\
Air-dry / Longitudinal & 0.116 & 0.128 & 0.116 & 0.117 & 0.120 \\
Air-dry / Tangential & 0.121 & 0.122 & 0.124 & 0.119 & 0.125 \\
\hline
\end{tabular}




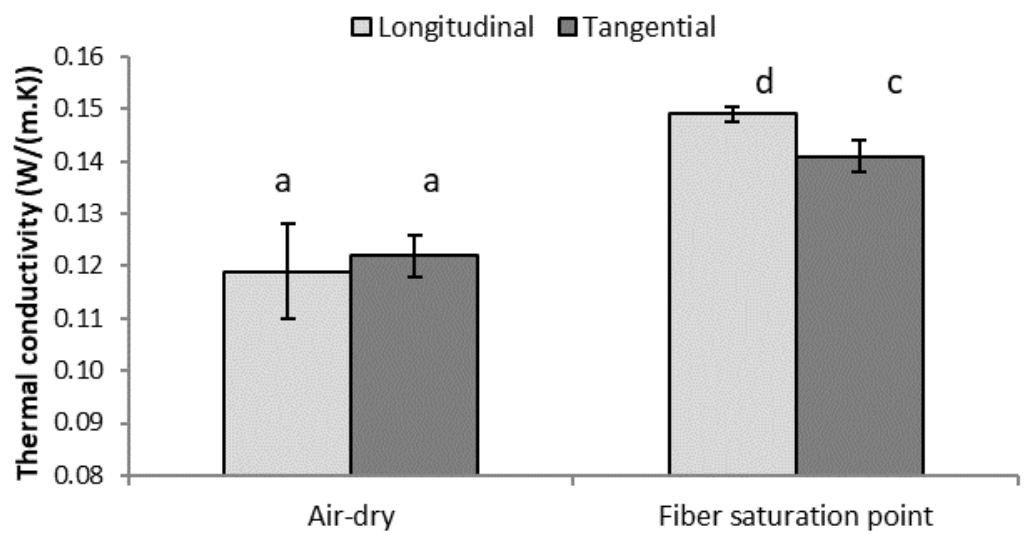

Figure 3. Thermal conductivity of teak wood related to fiber direction and moisture content. Mean of three trees, with the standard deviation error bar. The same letters are not statistically different at $P<0.05$ by Tukey's test.

Density is one of the most important factors that affect the thermal conductivity during the transmission of heat through the wood. Previously, significant correlations were found between the TC and SG as well as with strength properties for several species (Dündar et al. 2012). Figures 4 and 5 present the relationship between SG and TC at airdry and FSP conditions. Furthermore, a strong relationship was found in the longitudinal direction at the air-dried condition in the various trends (Figure 4a). However, TC had an inverse trend with SG, particularly in the 20-yearsold tree at the same condition (Figure 4b), while no consistent trend was observed between the two in a tangential direction (Figure $5 b$ ) at FSP. For longitudinal heat flow, the influence of density on the thermal conductivity was higher compared to the transversal heat flow due to the high portion of the secondary layer of the total cell wall and the orientation of microfibrils (Vay et al. 2015).

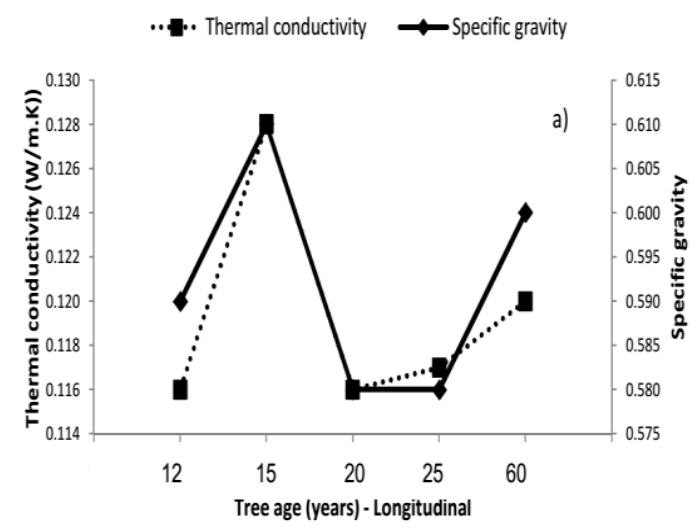

This present finding also showed that the variability of SG could not explain all the variable thermal conductivity variables at different conditions. However, TC was technically influenced by factors, such as wood species, density, widths of growth rings, the volumetric fraction of wood rays, and the latewood content. Other factors were the location in the cross-section of sapwood, heartwood, and juvenile wood, alongside on the stem (Olek et al. 2003). In addition, chemical content and type of extractives materials of wood are considerable factors affecting thermal properties (Yapici et al. 2011). In teak wood, as the tree age increased, the content of extractives increased (Lukmandaru and Takahashi 2008). Therefore, the chemical properties might also affect the obtained pattern of TC values.Therefore, the variations of TC can be attributed to variations of different anatomical and chemical features among the tree ages, which was not measured in this experiment.

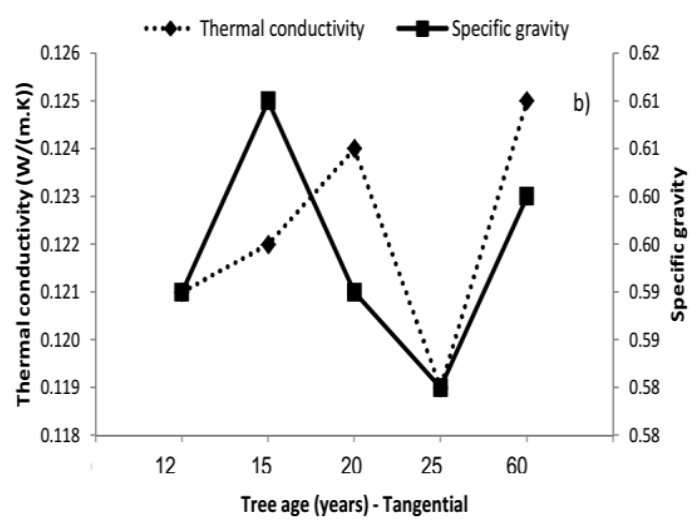

Figure 4. Thermal conductivity versus specific gravity in the longitudinal (a) and tangential (b) directions for teak wood from various tree ages at air-dry condition. 

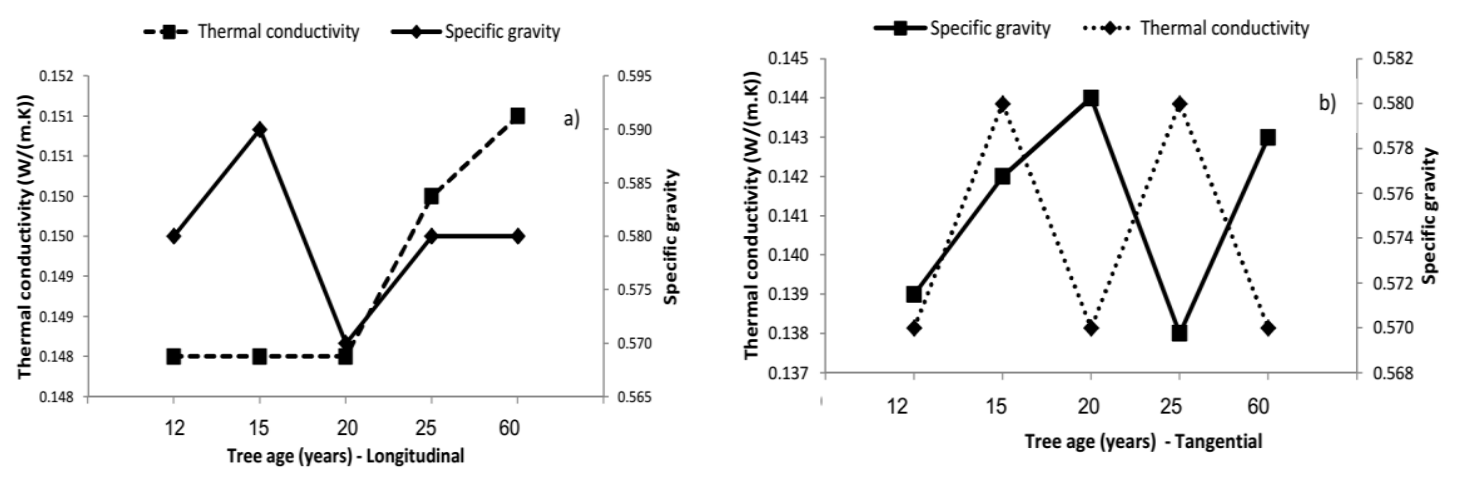

Figure 5.Thermal conductivity versus specific gravity in the longitudinal (a) and tangential (b) directions for teak wood from various tree ages at fiber saturation point.

\section{Conclusions}

The thermal conductivity values from different tree ages were 0.116 to 0.128 in $\mathrm{W} / \mathrm{mK}$ at the air-dry condition and 0.338 to $0.151 \mathrm{~W} / \mathrm{mK}$ at fiber saturation point. The tree ages did not have a significant effect on the conductivity, and no consistent trend was observed between specific gravity and the thermal conductivity values. Also, other indicated factors such as the orientation of microfibrils, widths of growth rings, volumetric fraction of wood rays and extractive content were likely to affect the values with increasing tree ages.

\section{References}

American Society for Testing and Material. 1978. ASTM C177. Standard test method for steady-state heat flux measurements and thermal transmission properties by means of the guarded-hot-plate apparatus. USA.

British Standard Institution. 1957. BS 373 Methods of Testing Small Clear Specimen of Timber. London.

Dündar, T.; Ş. Kurt; N. As; B. Uysal. 2012. Nondestructive evaluation of wood strength using thermal conductivity. Bioresources 7(3): 3306-3316.

Hidayati, F.; J. Sulistyo; G. Lukmandaru; T. Listyanto; H. Praptoyo; R. Pujiarti. 2015. Physical and mechanical properties of 10-year old superior and conventional teak planted in Randublatung, Central Java, Indonesia. Jurnal IImu Teknologi Kayu Tropis 13(1): 11-21.

Lukmandaru, G.; K. Takahashi. 2008. Variation in the natural termite resistance of teak (Tectona grandis L.f.) as a function of tree age. Annals of Forest Science 65 (7): 708 p1 - p8.

Marsoem, S.N.; V.E.Prasetyo; J. Sulistyo; Sudaryono; G. Lukmandaru. 2014. Studi mutu kayu jati di hutan rakyat Gunungkidul. III. Sifat fisika kayu. Jurnal IImu Kehutanan 8(2): 75-88.
Mauranen, A.; M. Ovaska; J. Koivisto; L. I. Salminen; M. Alava. 2015.Thermal conductivity of wood: effect of fatigue treatment Wood Science and Technology 49: 359-370.

Olek, W.; J. Weres; R. Guzenda. 2003. Effects of Thermal Conductivity Data on Accuracy of Modeling Heat Transfer in Wood. Holzforschung 57: 317-325.

Prasojo, A.; J. Sulistyo; T. Listyanto. 2012. Konduktivitas panas empat jenis kayu dalam kondisi kadar air yang berbeda. Prosiding Seminar Nasional MAPEKI XIV. p. 97-101. Yogyakarta

Siau, J.F. 1995. Wood : influence of moisture on physical properties. Department of Wood Science and Forest Products Virginia Polytechnic Institute and State University.

Sonderegger. W.; S. Hering; P. Niemz. 2011. Thermal behavior of Norway spruce and European beech in and between principal anatomical directions. Holzforschung 65: 369-375.

Suleiman, B. M.; J. Larfeldt; B. Leckner; M. Gustavsson. 1999. Thermal conductivity and diffusivity of wood. Wood Science and Technology 33: 465-473.

Vay, O.; K.D. Borst; C. Hansmann; A. Teischinger; U. Muller. 2015. Thermal conductivity of wood at angles to the principal anatomical directions. Wood Science and Technology 49: 577-589.

Yapici, F.I.; A. Ozcifci; R. Esen; S. Kurt. 2011. The effect of grain angle and species on thermal conductivity of some selected wood species. Bioresources 6(3): 2757-2762.

Veriawan Setyo Wibowo and Joko Sulistyo

Department of Forest Products Technology, Faculty of

Forestry, Universitas Gadjah Mada

Jl. Agro No.1, Bulaksumur, Yogyakarta 55281, Indonesia,

Tel. : : +6274 550541

Fax. : +6274 550541

E-mail : jsulistyo@ugm.ac.id 